\title{
Egészségfejlesztő projektek a Sapientia Erdélyi Magyar Tudományegyetem Életminőség Kutatóközpontjában. Kutatás és oktatás
}

\author{
Health promotion projects at the Quality of Life Research Centre, \\ Sapientia Hungarian University of Transylvania. Research and education
}

\author{
Szerzők: Sántha Ágnes $\bigotimes$, Lukács-Márton Réka, Harangus Katalin \\ Sapientia Hungarian University of Transylvania, Faculty of Tehnical and Human Sciences \\ Tirgu Mures, Department of Applied Social Sciences
}

Beküldve: 2018. 11. 01.

doi: 10.24365/ef.v59i5.377

Kulcsszavak: egészségfejlesztés; egészségügyi ápolók; kézhigiénia; mentális egészség

Keywords: health promotion; medical assistants; hand hygiene; mental health

2010-ben indult útjára egyetemünkön a közegészségügy alapképzés, amely nagy vonalakban a magyarországi népegészségügyi ellenőr szakiránynak felel meg. Hogy miért nem egy orvosi egyetem keretei között? Nos, ennek az az egyszerű oka, hogy Romániában ezt a szakot a közigazgatás, nem pedig az egészségtudományok közé sorolták be, és e tudományági besorolás okán a helye egy közigazgatástudományi képzésben van. Noha a román Oktatási Minisztérium csak 2016-ban rendelkezett először a képzés kimeneti követelményeiről(!), szakunk különlegességét mindig a prevenciós tevékenységek és az egészségfejlesztő kutatási irányvonal adta. Ennek jegyében végezzük ma is kutatási és oktatási tevékenységeinket, és az idei évtől már a tantervünkben is szerepel az Egészségfejlesztés tantárgy. A szak oktatói az Életminőség Kutatóközpont keretei között végeznek kutatómunkát, tagjai vagyunk a Népegészségügyi Képző- és Kutatóhelyek Egyesületének (NKE).

Magyarországi partnereink a Semmelweis Egyetem Egészségügyi Közszolgálati Kar, a Debreceni Egyetem Egészségügyi Kar (Nyíregyháza) és Egészségtudományi Kar. A jelenleg zajló kutatási projektjeink java része is ezekhez az együttmúködésekhez köthető. 2017-ben indítottuk az egészségügyi ápolók társadalmi helyzete, munkával való elégedettsége és egészségi állapota című, az állami egészségügyi szektor dolgozóit célzó kutatásunkat. Kutatócsoportunk tagjai: dr. Sántha Ágnes szociológus, dr. Harangus Katalin informatikus és dr. Lukács-Márton Réka pszichológus.

Standardizált kérdőívünket a Semmelweis Egyetem kutatócsoportja dolgozta ki (kutatásvezető dr. Vingender István). Eredményeink ez idáig az állami szektor dolgozóira terjednek ki, ezekből két publikáció, két szakdolgozat, három TDK-dolgozat és egy mesteri disszertáció született. A felmérés sikerét Sófalvi Andrea hallgatónk OTDK-jelölése koronázta meg. A közeljövőben azonos módszertannal az egyre növekvő magánszektor egészségügyi ápolóinak helyzetét tervezzük feltérképezni. Az MTA szakmódszertan pályázata által támogatott, MTA-SE Egészségnevelés kortárs-oktatással (TANTUdSZ) kutatócsoport munkájába kisebb léptékkel szakunk oktatói és hallgatói is bekapcsolódtak (kutatásvezető dr. Falus András akadémikus). A csoport szerteágazó egészségfejlesztő tevékenységei közül szakunk hallgatói a kézhigiéniakézmosó programnak egy pilot tevékenységét valósították meg egy marosvásárhelyi iskola elemi tagozatos tanulóival. Jelenleg az utómérés zajlik. 
Ezúton is köszönjük a Hand-in-Scan Kft. nagyvonalú támogatását, hiszen ingyenesen rendelkezésünkre bocsátott egy Semmelweis Hand Hygiene Scanner készüléket, mellyel a kézmosás hatékonyságát egzakt módon mérhetjük. A jó hangulatú, többszörösen "visszatapsolt”, vidéki iskolákba is invitált programunkról álljon itt ízelítőnek néhány fotó. Legfrissebb projektünk dr. Lukács-Márton Réka kutatócsoport-vezető nevéhez kötődik és az egyetemi hallgatók mentális egészségét méri. Kutatásunk ismét a szakmai együttmúködés szép példája, hiszen egyszerre zajlik a Debreceni Egyetemen, a Sapientia EMTE három karán (Kolozsvár, Marosvásárhely, Csíkszereda), valamint a komáromi Selye János Egyetemen. Méréseinket október hónapban kezdtük a Magyar Tudományos Akadémia Domus szülőföldi csoportos ösztöndíj anyagi támogatásával, eredményeinkről reményeink szerint a folyóirat egy későbbi számában beszámolhatunk.
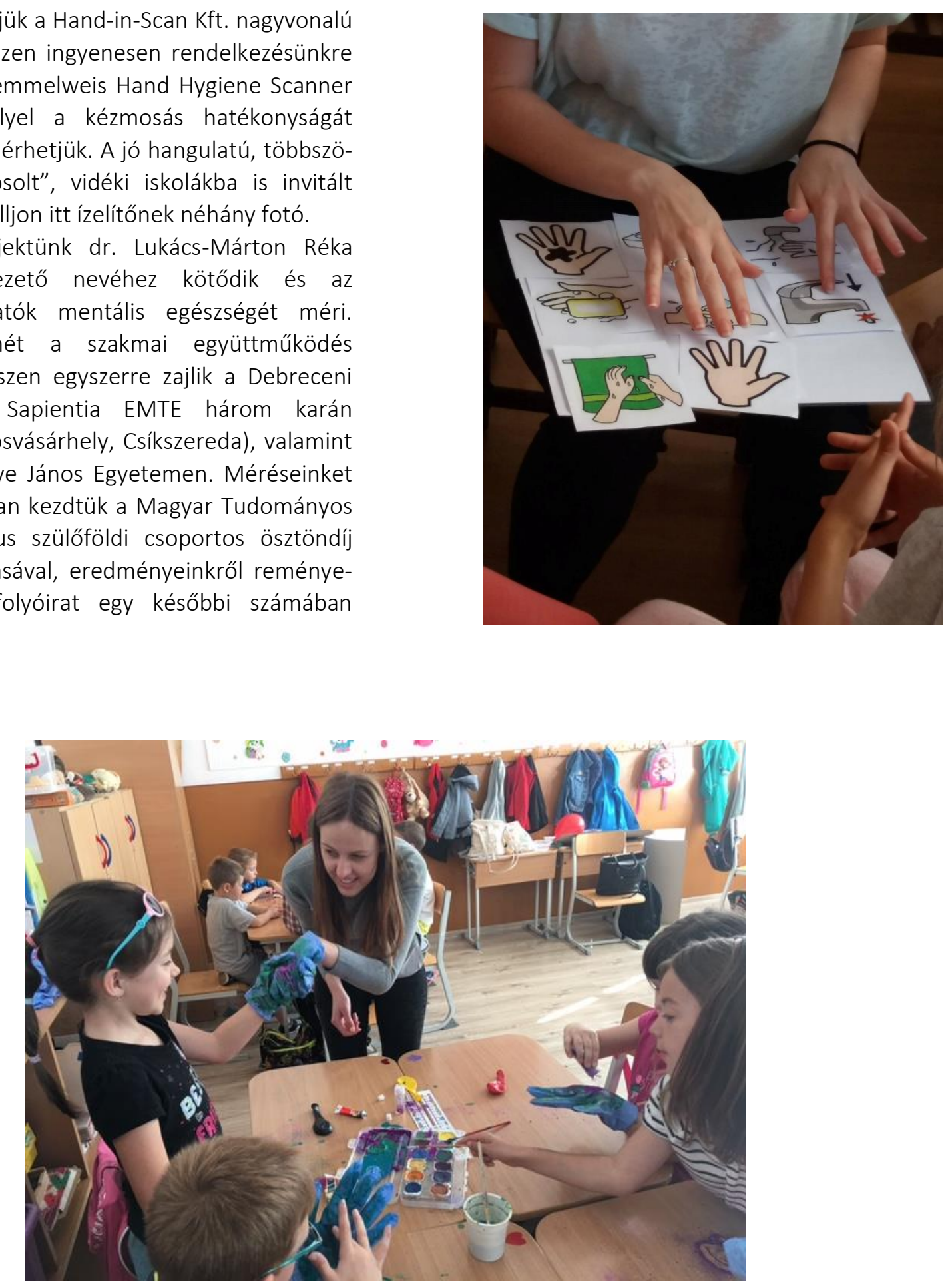